\title{
Kualitas Organoleptik Telur Itik yang Diberi Pakan Maggot Hidup (Hermetia illucens)
}

\author{
Aam Gunawan ${ }^{1)}$ \\ ${ }^{1}$ Program Studi Peternakan, Fakultas Pertanian, Universitas Islam Kalimantan MAB Banjarmasin \\ Email: aamgunawanenju@gmail.com
}

\begin{abstract}
Maggot black soldier fly (Hermetia illucens) is a protein source of feed which is highly favored by poultry, especially ducks and chickens. However, it is feared that the provision of live maggot in ducks will affect the organoleptic quality of the egg, especially its taste and aroma. Therefore this study aims to determine the organoleptic quality of duck eggs fed Hermetia illucens maggot feeds in a living state. The study used 120 alabio ducks which were placed in a postal cage. The design used was a completely randomized design, each treatment using six replications. Each replication is taken egg sample to be tested panelists. The panelists used were 67 panelists who were somewhat trained. The data obtained were analyzed of variance and Duncan's multiple range test. The treatments that were tried consisted of P1: low protein rations without live maggot, $\mathrm{P} 2$ : low protein rations with live maggot administration $40 \mathrm{~g} / \mathrm{bird} / \mathrm{day}, \mathrm{P} 3$ : high protein rations without live maggot administration, and $\mathrm{P} 4$ : high protein rations with live maggot administration $40 \mathrm{~g} / \mathrm{bird} / \mathrm{day}$. The results showed that the treatment affected the texture, flavor, and aroma of boiled eggs. Ducks fed with high protein ration coupled with the provision of live maggot $40 \mathrm{~g} / \mathrm{bird} / \mathrm{day}$ produce softer textures, tastes quite good, and aroma more fishy.
\end{abstract}

Keywords: Maggot, duck eggs, organoleptics

\section{PENDAHULUAN}

Pengembangan peternakan perlu ditunjang oleh penguasaan manajemen beternak dan pengadaan bibit yang baik serta penyediaan ransum yang berkualitas dengan harga yang relatif murah. Sedemikian pentingnya peranan ransum pada usaha peternakan unggas sehingga peran biaya tersebut mencapai 70-80 \% dari total biaya produksi. Donohue dan Cunningham (2009) menyatakan bahwa biaya pakan untuk ayam broiler dapat mencapai lebih dari $70 \%$ porsi utamanya untuk memenuhi kebutuhan energi metabolis. Untuk mengurangi biaya pakan perlu dicari pakan alternatif yang lebih murah namun mengandung nutrien yang lengkap. Salah satu bahan pakan alternatif yang mulai dilirik saat ini adalah maggot.

Beberapa hasil penelitian menunjukkan bahwa maggot layak digunakan sebagai alternatif sumber pakan untuk unggas (Despines dan Axtell, 1995). Kandungan lemak yang tinggi pada maggot Hermetia illucens yaitu berkisar 22-33\% (Gunawan, 2012) dapat mempengaruhi kualitas telur, seperti warna kuning telur, citarasa, tektur dan bau. Maggot H. illucens menurut Olivier (2000) mengandung $44 \%$ berat kering, $42,1 \%$ protein, $34,8 \%$ lemak.

Kualitas organoleptik telur seperti warna, bau dan rasa telur telah terbukti dipengaruhi oleh pakan yang diberikan. Simanjuntak dkk. (2013) menambahan daun katuk pada ransum dan terbukti mempengaruhi warna, bau, dan rasa telur itik, sedangkan Apriani dkk. 2017 menambahkan tepung daun mengkudu pada ransum burung puyuh dan ternyata semakin tinggi penambahan tepung daun mengkudu, warna kuning telur semakin kemerahan. Oleh karena itu penelitian ini bertujuan untuk mengetahui sampai seberapa besar pengaruh dari pemberian maggot hidup terhadap kualitas organoleptik telur itik yang dihasilkan.

\section{Rumusan Masalah}

1) Apakah terdapat perbedaan kualitas organoleptik telur dari itik yang diberi tambahan pakan maggot Hermetia illucens hidup. 
2) Apakah terdapat perbedaan kualitas organoleptik dari telur yang diberi pakan berprotein tinggi dengan rendah.

3) Kualitas organoleptik telur terbaik berasal dari itik yang diberi pakan apa?

\section{METODE PENELITIAN}

\section{Bahan}

1. Maggot BSF hidup, fase prepupa. Maggot BSF hidup diperoleh dari hasil budidaya menggunakan media bungkil inti sawit dan bahan organik lainnya.

2. Ternak Percobaan. Penelitian ini menggunakan itik Alabio sebanyak 120 ekor, berumur 7 bulan dan dibagi secara acak ke dalam 24 unit kandang cages. Masing-masing kandang diisi dengan lima ekor itik.

3. Ransum percobaan. Bahan penyusun ransum terdiri dari: konsentrat itik, dedak halus, jagung, dan tepung ikan, Komposisi ransum percobaan disajikan pada Tabel 1, sedangkan susunan dan kandungan nutrien ransum percobaan disajikan pada Tabel 2.

\section{Alat Penelitian}

1. Baskom, dengan diameter $50 \mathrm{~cm}$ dan tinggi 30 $\mathrm{cm}$ sebanyak 50 buah digunakan untuk tempat bungkil inti sawit dan bahan organik lainnya.

2. Timbangan digital merek oxone kapasitas $5 \mathrm{~kg}$ dengan ketelitian $1 \mathrm{~g}$, digunakan untuk menimbang pakan, itik, telur dll.

3. Kandang terbuat dari bahan-bahan seperti kayu, bambu, atap seng dengan luas $5 \times 12 \mathrm{~m}$. Di dalam kandang terdapat petak kandang berukuran $150 \times 200 \times 60 \mathrm{~cm}$ sebanyak 24 petak. Alas kandang terbuat tanah yang dipadatkan. Tempat minum yang digunakan terbuat dari talang PVC memanjang dan tempat pakan yang digunakan berupa baskom berdiameter $30 \mathrm{~cm}$ sebanyak 24 buah.

\section{Metode Penelitian \\ Rancangan Percobaan}

Rancangan yang digunakan yaitu rancangan acak lengkap (RAL) dengan empat perlakuan dan enam kali ulangan. Perlakuan tersebut adalah.:

P1 = Ransum Rendah Protein (15\%) + Maggot BSF Hidup (0 g/ekor/hari)
$\mathrm{P} 2=$ Ransum Rendah Protein $(15 \%)+$ Maggot BSF Hidup (40 g/ekor/hari)

P3 = Ransum Tinggi Protein (21\%) + Maggot BSF Hidup (0 g/ekor/hari)

P4 = Ransum Tinggi Protein $(21 \%)+$ Moggot BSF Hidup (40 g/ekor/hari)

Tabel 1. Komposisi Nutrien Bahan Pakan Penyusun Ransum Percobaan (as-fed)

\begin{tabular}{lcc}
\hline Bahan pakan & $\begin{array}{c}\text { Protein } \\
\text { kasar } \\
(\%)\end{array}$ & $\begin{array}{c}\text { M.E } \\
\text { Kcal/Kg }\end{array}$ \\
\hline Konsentrat itik $^{1}$ & 38,00 & 3.300 \\
Dedak halus $^{2}$ & 14,67 & 2.005 \\
Jagung $^{2}$ & 8,50 & 3.244 \\
Tepung ikan $^{2}$ & 42,76 & 2.845 \\
\hline
\end{tabular}

${ }^{1}$ Produksi PT. Wonokoyo Jaya Corporindo Surabaya)

${ }^{2}$ Analisis Laboratorium Makanan Ternak Universitas Padjadjaran, 2016)

Tabel 2. Susunan dan Kandungan Nutrien Ransum Percobaan

\begin{tabular}{|c|c|c|}
\hline \multirow[t]{2}{*}{ Bahan pakan } & \multicolumn{2}{|c|}{ Ransum perlakuan } \\
\hline & $\begin{array}{l}\text { Protein } \\
\text { rendah }\end{array}$ & $\begin{array}{l}\text { Protein } \\
\text { tinggi }\end{array}$ \\
\hline & \multicolumn{2}{|c|}{-----------(\%) ----- } \\
\hline Konsentrat itik & 17,00 & 17,00 \\
\hline Dedak halus & 24,10 & 21,40 \\
\hline Jagung & 58,90 & 43,60 \\
\hline Tepung ikan & 0 & 18,00 \\
\hline Total & 100 & 100 \\
\hline \multicolumn{3}{|c|}{ Kandungan nutrien } \\
\hline Protein kasar (\%) & 15,00 & 21,00 \\
\hline $\begin{array}{l}\text { Energi metabolis } \\
(\mathrm{kcal} / \mathrm{kg})\end{array}$ & 2.954 & 2.916 \\
\hline
\end{tabular}

\section{Prosedur Penelitian}

(1) Produksi maggot

Baskom sebanyak 20 buah masing-masing diisi dengan $3 \mathrm{~kg}$ bungkil inti sawit dan 6 liter air, ditutup dengan daun pisang kering. Dibiarkan di tempat terbuka selama 3 minggu. Maggot yang terdapat dalam baskom dipanen, selanjutnya ditimbang dan diberikan pada itik

(2) Penempatan itik

Itik yang baru datang dimasukkan pada masing-masing petak kandang yang sebelumnya dilakukan penimbangan berat badan awal yang seragam. Itik ditempatkan pada petak kandang 
masing-masing diisi 5 ekor. Setelah itu itik diberikan ransum penelitian sesuai dengan keempat macam perlakuan. Sebelum diberikan, masing-masing bahan ransum perlakuan dicampur satu sama lain dengan prosedur sebagai berikut: masing-masing bahan baku ditimbang sesuai dengan keperluan, pada tiap perlakuan dicampur sampai benar-benar homogen.

Ransum diberikan 2 kali sehari atau ad libitum, yaitu pada pagi dan sore hari. Ransum diberikan kembali apabila didalam tempat makanan sudah benar-benar habis sedangkan air minum diberikan secara ad libitum. Semua petak kandang dilengkapi dengan tempat makan dan tempat minum yang sesuai dengan kebutuhan, untuk penerangan digunakan lampu pijar 15 watt.

Telur yang dihasilkan pada setiap petak perlakuan diberi tanda dan direbus selama 30 menit. Didinginkan dan dibelah menjadi 4 bagian untuk uji panelis. Panelis yang disiapkan merupakan panelis agak terlatih sebanyak 67 orang.

\section{Pengukuran Variabel Respon}

Variabel respon yang diamati terdiri dari tekstur, flavor/citarasa, dan bau. Pengukuran variabel tersebut menggunakan pengujian organoleptik dilakukan dengan metode preferences test (Susiwi, 2009) menggunakan panelis agak terlatih sebanyak 67 orang. Skor tekstur terdiri dari 1=sangat keras, 2=keras, 3=cukup, 4=lunak, dan $5=$ sangat lunak. Skor flavor/citarasa terdiri dari 1=amat sangat enak, 2=sangat enak, 3=enak, 4=cukup, 5=kurang enak, 6=tidak enak, dan $7=$ sangat tidak enak. Skor bau terdiri dari $1=$ amat sangat amis, 2=sangat amis, 3=amis, 4=cukup amis, $5=$ kurang amis, $6=$ tidak amis, dan $7=$ sangat tidak amis

\section{Analisis Data}

Data hasil pengamatan selama penelitian dikumpulkan, kemudian dilakukan analisis ragam untuk mengetahui perbedaan pengaruh perlakuan terhadap variabel yang diamati. Dilakukan uji homogenitas varian (uji bartlett). Apabila hasil analisis ragam menunjukan pengaruh nyata atau sangat nyata, maka pengujian dilanjutkan dengan uji Wilayah Berganda Duncan / Duncan Multiple Range Test (DMRT) menggunakan SPSS 23 for windows. (Steel and Torrie, 1982).

\section{HASIL DAN PEMBAHASAN \\ Tekstur}

Data hasil pengamatan kualitas organoleptik masing-masing perlakuan disajikan pada Tabel 3.

Tabel 3. Rata-rata kualitas organoleptik telur itik.

\begin{tabular}{lccc}
\hline \multirow{2}{*}{ Variabel } & \multicolumn{2}{c}{ Perlakuan } & $\begin{array}{c}\text { Skor rata- } \\
\text { rata } \pm \text { SEM }\end{array}$ \\
\cline { 2 - 3 } & Protein $(\%)$ & $\begin{array}{c}\text { Maggot } \\
\text { hidup }(\mathrm{g})\end{array}$ & \\
\hline Tekstur & 15 (Rendah) & 0 & $2.99 \pm 0.091^{\mathrm{a}}$ \\
& & 40 & $2.94 \pm 0.085^{\mathrm{a}}$ \\
& 21 (Tinggi) & 0 & $3.13 \pm 0.097^{\mathrm{a}}$ \\
& & 40 & $3.60 \pm 0.141^{\mathrm{b}}$ \\
\hline \multirow{3}{*}{ Flavor } & 15 (Rendah) & 0 & $3.34 \pm 0.078^{\mathrm{a}}$ \\
& & 40 & $3.48 \pm 0.098^{\mathrm{a}}$ \\
& 21 (Tinggi) & 0 & $3.40 \pm 0.124^{\mathrm{a}}$ \\
& & 40 & $3.82 \pm 0.163^{\mathrm{b}}$ \\
\hline \multirow{4}{*}{ Bau } & 15 (Rendah) & 0 & $3.87 \pm 0.110^{\mathrm{b}}$ \\
& & 40 & $3.94 \pm 0.114^{\mathrm{b}}$ \\
& 21 (Tinggi) & 0 & $3.39 \pm 0.097^{\mathrm{a}}$ \\
& & 40 & $3.07 \pm 0.146^{\mathrm{a}}$ \\
\hline
\end{tabular}

Keterangan: Huruf superskip yang berbeda pada baris yang sama menunjukkan pengaruh sangat nyata $(\mathrm{P}<0,01)$

Skor tekstur yang diperoleh pada penelitian ini berkisar 2.94-3.60 tergolong cukup lunak sampai lunak. Skor tertinggi $(3.60 \pm 0.141)$ diperoleh pada perlakuan ransum tinggi protein dengan penambahan maggot 40 g/ekor/hari, sedangkan skor tekstur terendah diperoleh $(2.94 \pm 0.085)$ pada perlakuan ransum rendah protein dengan penambahan maggot 40 g/ekor/hari. Berdasarkan hasil analisis ragam dapat diketahui bahwa perlakuan pemberian maggot BSF hidup dalam ransum rendah dan tinggi protein berpengaruh sangat nyata $(\mathrm{P}<0,01)$ terhadap tekstur telur rebus. Pemberian maggot hidup sebanyak 40 $\mathrm{g} /$ hari/ekor pada ransum tinggi protein memberikan nilai skor tekstur yang berbeda dengan ketiga perlakuan lainnya.

Ransum rendah protein ditambah dengan pemberian maggot hidup sebanyak 40 g/ekor/hari, ransum rendah protein ditambah dengan pemberian maggot hidup sebanyak 0 g/ekor/hari, dan ransum tinggi protein tanpa penambahan maggot hidup menghasilkan nilai skor tekstur yang relatif sama. Pemberian maggot hidup sebanyak 40 g/hari/ekor pada ransum tinggi protein dapat meningkatkan skor 
tekstur menjadi lebih lunak. Hal ini diduga karena kandungan lemak dan protein pada telur lebih tinggi dibandingkan dengan perlakuan lainnya. Kandungan lemak dan protein yang tinggi dalam telur, dikarenakan itik mengkonsumsi maggot dan protein yang ada dalam ransum. Penelitian Oktaviani, et.al. (2012) menyimpulkan bahwa kadar lemak dalam telur bebek dari bebek yang tidak mendapatkan pakan limbah udang berbeda nyata dengan telur bebek yang diberikan penambahan limbah udang.

\section{Flavor}

Skor flavor yang diperoleh pada penelitian ini berkisar 3.34-3.82 tergolong enak sampai cukup enak. Skor tertinggi $(3.82 \pm 0.163)$ diperoleh pada perlakuan ransum tinggi protein dengan penambahan maggot 40 g/ekor/hari, sedangkan skor flavor terendah diperoleh $(3.34 \pm 0.078)$ pada perlakuan ransum rendah protein dengan penambahan maggot $0 \mathrm{~g} / \mathrm{ekor} / \mathrm{hari}$. Berdasarkan hasil analisis ragam dapat diketahui bahwa perlakuan pemberian maggot BSF hidup dalam ransum rendah dan tinggi protein berpengaruh nyata $(\mathrm{P}<0,05)$ terhadap flavor telur rebus. Pemberian maggot hidup sebanyak 40 $\mathrm{g} /$ hari/ekor pada ransum tinggi protein memberikan nilai skor flavor yang berbeda dengan ketiga perlakuan lainnya.

Ransum rendah protein ditambah dengan pemberian maggot hidup sebanyak 40 g/ekor/hari, ransum rendah protein ditambah dengan pemberian maggot hidup sebanyak 0 g/ekor/hari, dan ransum tinggi protein tanpa penambahan maggot hidup menghasilkan nilai skor flavor yang relatif sama. Pemberian maggot hidup sebanyak 40 g/hari/ekor pada ransum tinggi protein dapat meningkatkan skor flavor/citarasa menjadi cukup enak. Hal ini diduga karena kandungan lemak dan protein pada telur lebih tinggi dibandingkan dengan perlakuan lainnya. Oktaviani et. al. (2012) menyatakan bahwa komposisi pakan yang diberikan berbeda akan mempengaruhi kadar lemak dalam telur bebek. Kadar lemak dalam telur inilah yang lebih banyak menentukan citarasa. Makin tinggi kandungan lemak dan protein maka citarasa akan semakin kurang enak karena lebih berbau amis.

Skor flavor dari hasil penelitian ini hampir sama dengan skor flavor dari penelitian Simanjuntak et.al (2013) yang mendapatkan skor rasa sebesar 2,75-3,59 dengan kisaran rasa cukup enak sampai enak. Hasil penelitian Apriani et. al. (2017) rasa telur puyuh memiliki nilai antara 2,93 - 3,10 yang menunjukkan nilai rasa telur puyuh mempunyai nilai yang berbeda pada masing - masing perlakuan. Hal tersebut dapat terjadi karena adanya kandungan antioksidan dalam tepung daun mengkudu yang dapat mengurangi kandungan lemak dalam telur.

\section{Bau}

Skor bau yang diperoleh pada penelitian ini berkisar 3.07-3.94 tergolong amis sampai cukup amis. Skor tertinggi $(3.94 \pm 0.114)$ diperoleh pada perlakuan ransum rendah protein dengan penambahan maggot $40 \mathrm{~g} / \mathrm{ekor} / \mathrm{hari}$, sedangkan skor tekstur terendah $(3.07 \pm 0.146)$ diperoleh pada perlakuan ransum tinggi protein dengan penambahan maggot $40 \mathrm{~g} / \mathrm{ekor} / \mathrm{hari}$. Berdasarkan hasil analisis ragam dapat diketahui bahwa perlakuan pemberian maggot BSF hidup dalam ransum rendah dan tinggi protein berpengaruh sangat nyata $(\mathrm{P}<0,01)$ terhadap bau telur rebus.

Pemberian maggot hidup sebanyak 40 $\mathrm{g} /$ hari/ekor dan $0 \mathrm{~g} /$ ekor/hari pada ransum tinggi protein memberikan nilai skor bau yang relatif sama, begitu pula antara perlakuan pemberian maggot 40 g/ekor/hari dan 0 g/ekor/hari pada ransum rendah protein memberikan skor bau yang relatif sama. Jadi yang lebih menentukan perbedaan terhadap skor bau adalah kandungan protein ransum. Ransum tinggi protein dapat menurunkan skor bau menjadi lebih amis. Hal ini diduga karena kandungan lemak dan protein pada telur lebih tinggi dibandingkan dengan perlakuan lainnya. Simanjuntak et.al. (2013) menyatakan bahwa pemberian tepung daun katuk (Sauropus androgynus) dengan level 5-7,5\% dalam ransum dapat meningkatkan rasa telur, meningkatkan warna kuning telur, dan mengurangi bau amis. Hal ini diduga juga terjadi penurunan kandungan lemak pada telur itik. Skor bau telur itik yang diperoleh pada penelitian ini hampir sama dengan skor bau yang diperoleh dari hasil penelitian Simanjuntak, et.al. dengan skor bau telur itik berkisar 3,01-3,98.

\section{KESIMPULAN}

Pemberian maggot BSF hidup sebesar 40 g/ekor/hari terutama pada ransum berkadar protein tinggi dapat menghasilkan kualitas orgaleptik telur 
itik dengan kriteria tekstur lebih lunak, flavor cukup enak, dan bau lebih amis.

\section{Ucapan Terima Kasih}

Penulis mengucapkan terima kasih kepada Direktur Riset dan Pengabdian Masyarakat, Direktorat Jenderal Penguatan Riset dan Pengembangan Kemristekdikti dan Ketua Umum Badan Pengurus Yayasan Universitas Islam Kalimantan Muhammad Arsyad Al Banjari yang telah memberikan bantuan anggaran penelitian kepada penulis.

\section{DAFTAR PUSTAKA}

Apriani,L., R. E. Mudawaroch, J. Mediantari, dan W. Wibawanti. 2017. Pengaruh Suplementasi Tepung Daun Mengkudu (Morinda citrifolia L.) Dalam Pakan Komersil Terhadap Warna Kuning dan Organoleptik Telur Puyuh (Coturnix coturnix japonica). Surya Agritama Volume 6(2):50-62.

Despines, J.L. and Axtell, R.C. 1995. Feeding Behavior and Growth of Broiler Chicks Fed Larvae of Darkling Beetle Alphitobius diaperinus. Poult. Sci. 74:331-336.

Donohue, M. and D.L. Cunningham, 2009. Effects of grain and oilseed prices on the costs of US poultry production. J. Appl. Poult. Res., 18: 325-337

Gunawan, A. 2012. Aplikasi Maggot Black Soldier Fly (Hermetia illucens) yang Dibiakkan dalam Manur Unggas sebagai Campuran Pakan Periode Pertumbuhan dan Produksi Telur Puyuh (Coturnix coturnix japonica). Disertasi. Program Pascasarjana Universitas Padjadjaran Bandung.

Gunawan, A., N. Widaningsih dan M.Syarif D. 2012. Nilai Energi Metabolis dan Retensi Nitrogen Maggot yang Berasal dari Berbagai Jenis Manur pada Burung Puyuh. Media Sains. 4(2):109-116.

Olivier PA. 2000. Larval Bio-conversion. Econference: Area-Wide Integration of Specialized Crop and Lifestock Production. $18^{\text {th }}$ June- $3^{\text {rd }}$ August 2000. Melalui http://leadfr..vurtualcentre.org/en/ele/awi_2000/downloa ds.htm [01/05/2009]
Oktaviani, H., N. Kariada, N. Rahayu Utami. 2012. Pengaruh Pengasinan terhadap Kandungan Zat Gizi Telur Bebek yang Diberi Limbah Udang. Unnes J Life Sci 1 (2):106-112.

Simanjuntak, R.,Urip Santoso, Tris Akbarillah. 2013. Pengaruh Pemberian Tepung Daun Katuk (Sauropus androgynus) Dalam Ransum Terhadap Kualitas Telur Itik Mojosari. Jurnal Sain Peternakan. 8:65-76.

Steel, R.G.D. and J.H. Torrie. 1982. Prinsip dan Prosedur Statistika: Suatu Pendekatan Biometrik. Edisi Kedua. Terjemahan Bambang Sumantri. Jakarta:Gramedia Pustaka Utama.

Susiwi, S. 2009. Pengujian Organoleptik. Handbook Mata Kuliah Regulasi Pangan. Jurusan Pendidikan Kimia Universitas Pendidikan Indonesia. Bandung.

Utama, C.S., I. Estiningdriati, V. Dwi Yunianto dan W. Murningsih. 2007. Pengaruh Penambahan Aras Mineral pada Fermentasi Sorghum dengan Ragi Tempe terhadap Kecernaan Nutrien pada Ayam Petelur. Animal Production 9:14-17. 